\title{
The Hypoglycemic Action of Ketones. II. Evidence for a Stimulatory Feedback of Ketones on the Pancreatic Beta Cells *
}

\author{
Leonard L. Madison, David Mebane, $\dagger$ Roger H. Unger, and \\ AMANDA LOCHNER + \\ (From the Department of Internal Medicine, the University of Texas Southwestern Medical \\ School, Dallas, Texas)
}

The effects of alterations in carbohydrate metabolism induced by starvation and insulin deprivation on hepatic ketone production and peripheral ketone utilization have been the subject of intensive investigation (1-12). Only scant attention, however, has been paid to the effects that hyperketonemia, in turn, might have on carbohydrate and fat metabolism. The conflicting results from such studies (13-17) have been reviewed recently (18). Studies in this laboratory, designed to define the effects of induced hyperketonemia on carbohydrate and fat metabolism $(18,19)$, showed that iv infusions of $\beta$-hydroxybutyric acid, acetoacetic acid, or their sodium salts produced the following immediate changes in glucose and nonesterified fatty acid (NEFA) metabolism: 1) blood glucose concentration fell promptly, at times to distinctly hypoglycemic levels, 2) hepatic glucose output decreased sharply to less than $50 \%$ of control values, a reduction accounting entirely for the decrease in arterial glucose concentration, and 3) these changes in glucose metabolism were accompanied simultaneously by a greater than $50 \%$ fall in arterial plasma NEFA concentration. The qualitative similarity between ketone infusion and the slow iv administration of insulin (20) not

\footnotetext{
* Submitted for publication August 5, 1963 ; accepted November 7, 1963.

This work has been supported in large part by U. S. Public Health Service grant A-4236 from the National Institute for Arthritis and Metabolic Diseases and also by grants from the Upjohn and Pfizer Companies.

Presented before the Fifty-Fifth Annual Meeting of the American Society for Clinical Investigation, April 29, 1963.

$\dagger$ During tenure of U. S. Public Health Service postdoctoral fellowship (APD-17,224) of the National Institute for Arthritis and Metabolic Diseases.

$\ddagger$ During tenure of a predoctoral fellowship.
}

only on blood glucose concentration and hepatic glucose output but also on plasma NEFA concentration suggested the possibility that ketones produce these effects via stimulation of endogenous insulin secretion.

The present studies were designed specifically to determine whether ketone bodies stimulate the pancreatic $\beta$-cells, directly or indirectly, to secrete increased amounts of insulin. Two types of studies were performed: in the first group, the effects of hyperketonemia produced by infusions of $\beta$-hydroxybutyrate and acetoacetate on blood glucose concentrations were compared in depancreatized dogs and in dogs with alloxan diabetes; in the second group of studies, the changes in pancreatic venous insulin concentrations were determined by immunoassay during infusions of ketones either into a femoral vein or into a branch of the pancreatic artery.

\section{Methods}

In the studies designed to compare the effects of $\beta$-hydroxybutyrate and acetoacetate on the arterial glucose concentration of totally diabetic depancreatized and partially diabetic alloxanized dogs, experiments were performed at least 2 weeks after alloxanization (21) or total pancreatectomy to permit complete recovery. Pancreatectomy was performed and postoperative treatment carried out according to the technique of Markowitz, Archibald, and Downie (22). The diabetic state was controlled in both groups with NPH insulin, which was discontinued 12 to 20 hours before study. The time allowed to elapse after discontinuation of maintenance insulin in both the alloxanized and depancreatized groups was varied in an effort to obtain similar starting blood glucose concentrations in both groups so that a potentiating effect of ketones on administered insulin could be observed if it occurred in the depancreatized dogs. After an overnight fast the dogs were anesthetized with Nembutal (sodium pentobarbital). Arterial blood samples were obtained through an indwelling Cournand 
TABLE I

Effect of ketone infusion on arterial glucose and NEFA concentrations in dogs with alloxan-induced diabetes*

\begin{tabular}{|c|c|c|c|c|c|c|c|c|c|c|}
\hline \multirow[b]{2}{*}{ Dog } & & \multicolumn{3}{|c|}{ Minutes of control } & \multicolumn{6}{|c|}{ Minutes during and after infusion } \\
\hline & & -30 & -15 & $\mathbf{0}$ & 20 & 40 & 60 & 80 & 100 & 120 \\
\hline AD 1 & $\begin{array}{l}\text { Glucose } \\
\text { NEFA }\end{array}$ & $\begin{array}{l}124 \\
757\end{array}$ & $\begin{array}{l}126 \\
765\end{array}$ & $\begin{array}{c}134 \\
975 \\
\leftarrow 6\end{array}$ & $\begin{array}{r}129 \\
592 \\
, 6 \mathrm{~m}\end{array}$ & $\begin{array}{c}125 \\
439 \\
\mathrm{les} / \mathrm{kg}\end{array}$ & $\begin{array}{c}120 \\
385 \\
\text { our } \rightarrow\end{array}$ & $\begin{array}{l}110 \\
240\end{array}$ & $\begin{array}{r}97 \\
250\end{array}$ & $\begin{array}{r}87 \\
260\end{array}$ \\
\hline AD 2 & $\begin{array}{l}\text { Glucose } \\
\text { NEFA }\end{array}$ & $\begin{array}{l}174 \\
612\end{array}$ & $\begin{array}{l}173 \\
610\end{array}$ & $\begin{array}{c}179 \\
635 \\
\leftarrow 6\end{array}$ & $\begin{array}{r}179 \\
517 \\
, 6 \mathrm{mr}\end{array}$ & $\begin{array}{c}175 \\
326 \\
\text { les/kg }\end{array}$ & $\begin{array}{c}160 \\
280 \\
\text { our } \rightarrow\end{array}$ & $\begin{array}{l}149 \\
249\end{array}$ & $\begin{array}{l}129 \\
308\end{array}$ & $\begin{array}{l}116 \\
304\end{array}$ \\
\hline AD 3 & $\begin{array}{l}\text { Glucose } \\
\text { NEFA }\end{array}$ & $\begin{array}{r}220 \\
1,380\end{array}$ & 223 & $\begin{array}{r}227 \\
1,554 \\
\longleftarrow\end{array}$ & $\begin{array}{r}203 \\
1,011 \\
5 \mathrm{~mm}\end{array}$ & $\begin{array}{c}198 \\
808 \\
\mathrm{~s} / \mathrm{kg} / \mathrm{h}\end{array}$ & $\begin{array}{c}195 \\
800 \\
\stackrel{1}{\longrightarrow}-\longrightarrow\end{array}$ & $\begin{array}{r}203 \\
1,027\end{array}$ & 203 & $\begin{array}{r}201 \\
1,270\end{array}$ \\
\hline $\mathrm{AD} 4$ & $\begin{array}{l}\text { Glucose } \\
\text { NEFA }\end{array}$ & $\begin{array}{r}327 \\
1,231\end{array}$ & 326 & $\begin{array}{r}328 \\
1,356 \\
\leftarrow\end{array}$ & $\begin{array}{r}307 \\
1,159 \\
5 \mathrm{mmc}\end{array}$ & $\begin{array}{c}293 \\
761 \\
/ \mathrm{kg} / \mathrm{l}\end{array}$ & $\begin{array}{c}293 \\
541 \\
\mathrm{r} \longrightarrow\end{array}$ & $\begin{array}{l}282 \\
726\end{array}$ & 268 & $\begin{array}{r}270 \\
1,157\end{array}$ \\
\hline Mean & $\begin{array}{l}\text { Glucose } \\
\text { NEFA }\end{array}$ & $\begin{array}{l}211 \\
995\end{array}$ & 212 & $\begin{array}{r}217 \\
1,130\end{array}$ & $\begin{array}{l}205 \\
820\end{array}$ & $\begin{array}{l}198 \\
584\end{array}$ & $\begin{array}{l}192 \\
502\end{array}$ & $\begin{array}{l}186 \\
561\end{array}$ & 174 & $\begin{array}{l}169 \\
748\end{array}$ \\
\hline
\end{tabular}

* Glucose in mg per $100 \mathrm{ml}$; NEFA (nonesterified fatty acids) in $\mu$ Eq per L of plasma; AcAc = acetoacetate $\beta$-OHBA $=\beta$-hydroxybutyrate.

needle placed in a femoral artery, and glucose concentrations were determined in triplicate by the Somogyi copper-iodometric technique (23). After three control blood samples were collected at 15-minute intervals, $\beta$-hydroxybutyrate or acetoacetate was infused into a femoral vein over a period of 1 hour at a rate varying from 5 to 7 mmoles per $\mathrm{kg}$ per hour. The method of preparation of the ketone solutions has been described in a previous publication (18). Arterial blood samples were collected at 15- to 20-minute intervals during infusion and the ensuing hour.

The changes in pancreatic-venous plasma insulin concentration were followed in nine studies during infusions of $\beta$-hydroxybutyrate or acetoacetate. In five of these studies the ketones were injected into a femoral vein, and in the other four about $1 / 20$ the amount was infused into a branch of the pancreatic artery. The femoral infusions were administered at an average rate of 2.46 mmoles per minute ( 7.5 mmoles per $\mathrm{kg}$ per hour), and the pancreatic-arterial infusions, at a rate of 0.125 mmole per minute ( 0.341 mmole per $\mathrm{kg}$ per hour). The latter rate had no effect on blood glucose concentration or hepatic glucose output when administered intravenously. Pancreatic arterial infusions were carried out according to the technique of Colwell, Colwell, and Colwell (24). Pancreatic venous samples were collected through a polyethylene catheter placed in the portal vein opposite the entry of the pancreatic vein. At the time of sampling only, the catheter was advanced into the pancreatic vein. We attempted to prevent prolonged periods of obstruction of the pancreatic vein, since initial observations revealed that this caused capricious variation in

TABLE II

Effect of ketone infusion on arterial glucose concentration in depancreatized dogs

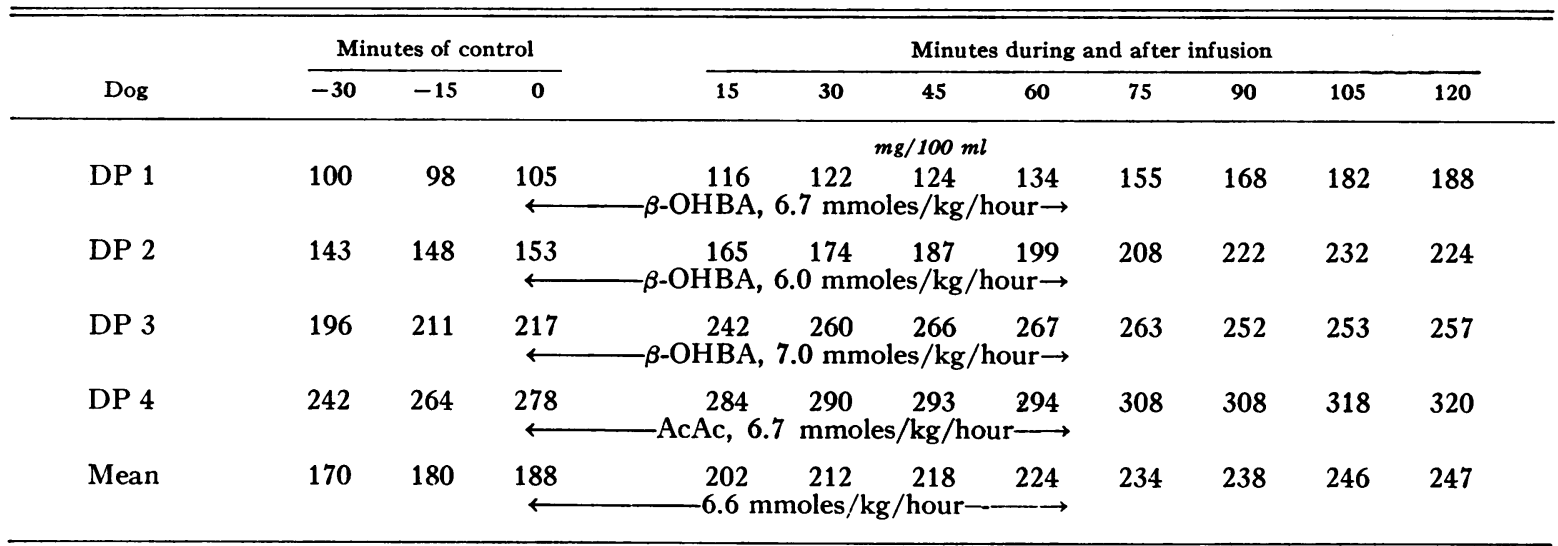




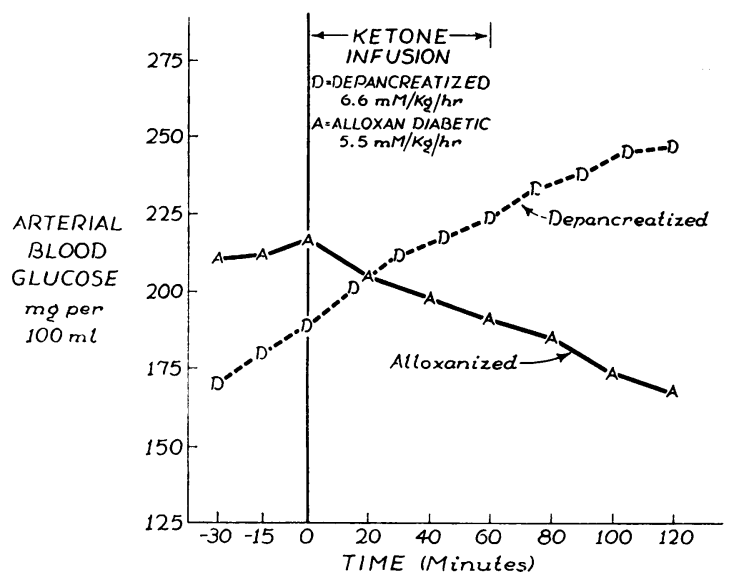

Fig. 1. CoMparison OF THE MEAN CHANGES IN ARTERIAL GLUCOSE CONCENTRATION DURING KETONE BODY INFUSION IN ALLOXAN-DIABETIC AND DEPANCREATIZED DOGS.

insulin concentrations of pancreatic effluent blood. After three control pancreatic venous samples were collected during saline infusion, $\beta$-hydroxybutyrate or acetoacetate was infused and samples collected at 15- to 20-minute intervals. Insulin concentrations were determined by the immunoassay method of Yalow and Berson (25), except that chromatographic rather than chromatoelectrophoretic separation of bound and free insulin- $\mathrm{I}^{131}$ was employed. The strips were then bisected and counted in a well-type gamma scintillation counter.

\section{Results}

Ketone infusion in depancreatized and alloxanized dogs. The iv administration of $\beta$-hydroxybutyrate or acetoacetate $(5.5$ mmoles per $\mathrm{kg}$ per hour) into the four alloxanized dogs resulted in a prompt decline in arterial glucose and NEFA concentration (Table I), an action qualitatively similar to the effects produced in nondiabetic dogs (18). This hypoglycemic action occurred in all four dogs despite variation in preinfusion arterial glucose concentration from 134 to $328 \mathrm{mg}$ per $100 \mathrm{ml}$. Mean arterial glucose concentration fell $22 \%$, from the control value of 217 to 169 $\mathrm{mg}$ per $100 \mathrm{ml}$ at 120 minutes. Simultaneously, arterial plasma NEFA concentration decreased from the mean control value of $1,130 \mu \mathrm{Eq}$ per $\mathrm{L}$ to $502 \mu \mathrm{Eq}$ per $\mathrm{L}$ at 1 hour.

In contrast, the administration of even larger amounts of ketone bodies ( 6.6 mmoles per $\mathrm{kg}$ per hour), which would be expected to produce an even greater hypoglycemic effect (18), failed to lower arterial glucose concentration in the four completely depancreatized dogs (Table II). The different responses of the alloxan diabetic and depancreatized dogs are contrasted in Figure 1. Mean arterial glucose concentration rose from 188 to $224 \mathrm{mg}$ per $100 \mathrm{ml}$ during the hour of ketone infusion. The failure of ketones to have a hypoglycemic action in depancreatized dogs with lower fasting blood glucose concentrations than those of the alloxanized dogs, coupled with the fall in blood glucose in the alloxan diabetic dogs, suggests that the pancreas is required for the hypoglycemic effect and that ketones do not potentiate the action of insulin already present in the experimental animal.

TABLE III

Effect of femoral-venous ketone infusion on pancreatic-venous insulin concentration

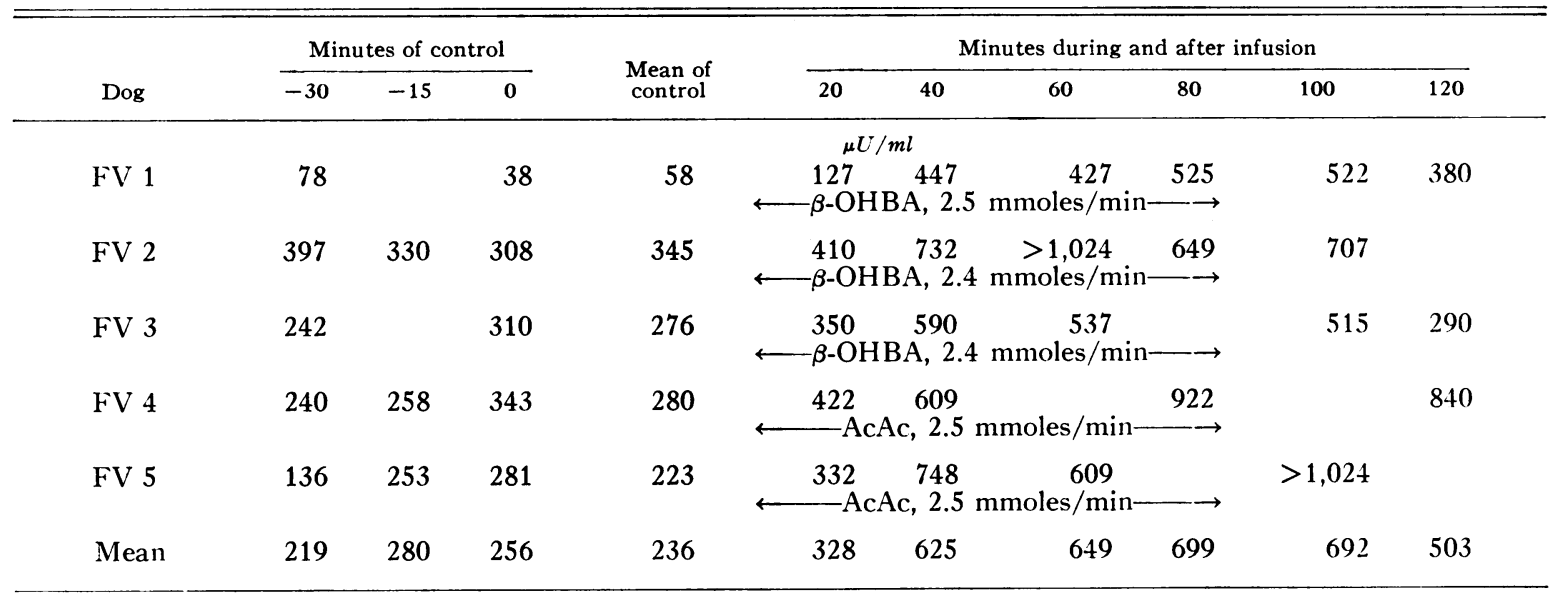




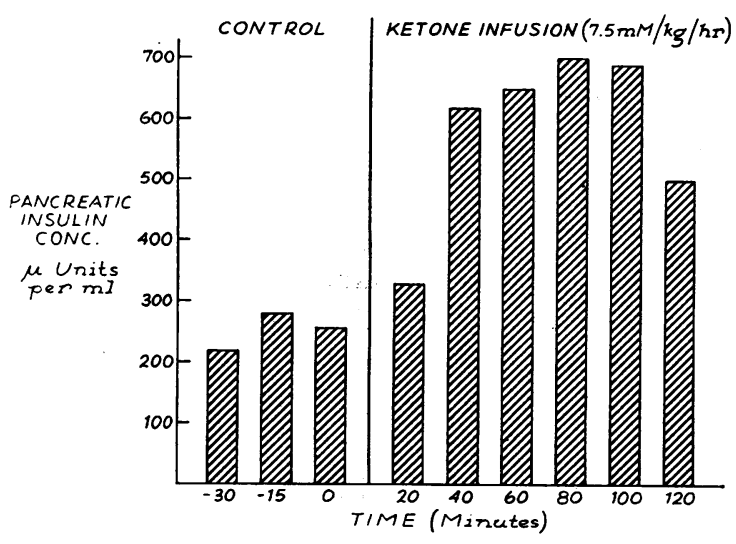

Fig. 2. Mean changes in Pancreatic-venous iNSULIN CONCENTRATION DURING FEMORAL-VENOUS INFUSIONS OF KETONE BODIES ADMINISTERED AT A RATE OF 2.45 M MOLES PER MINUTE.

Effect of femoral-venous ketone infusion on pancreatic-venous plasma insulin concentrations. In each of the five studies there was a significant rise in pancreatic-venous plasma insulin concentration within 20 minutes after starting the ketone infusion ( Table III) ; insulin concentrations rose progressively and reached a mean maximal value of $699 \mu \mathrm{U}$ per $\mathrm{ml}$ at 80 minutes, a $196 \%$ increase from the mean control value of $236 \mu \mathrm{U}$ per $\mathrm{ml}$ (Figure 2). At 120 minutes mean plasma insulin level was still above control.

Effect of pancreatic-arterial ketone infusion on pancreatic-venous plasma insulin concentrations. When as little as $1 / 25$ of the dose of ketone administered into the femoral vein was infused directly into the pancreatic artery, there was a rapid and progressive increase in pancreatic-

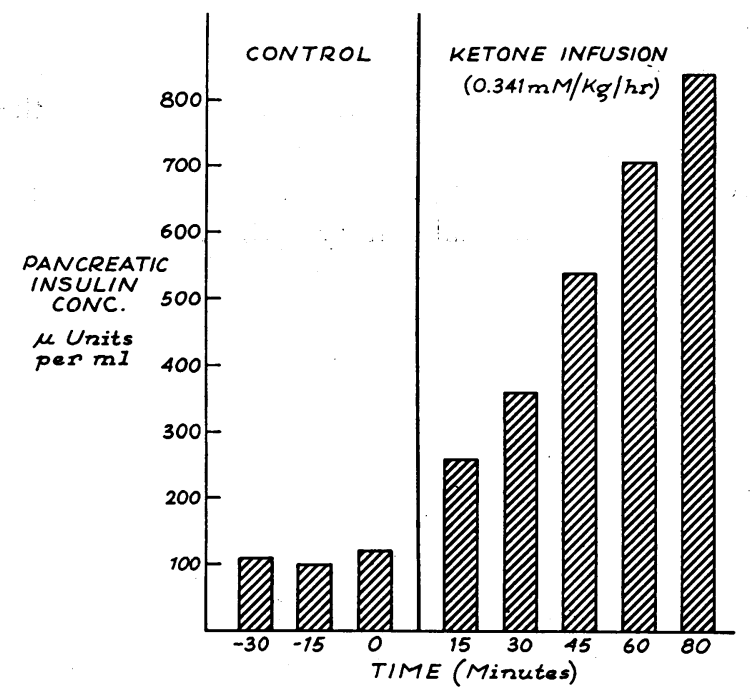

Fig. 3. Mean changes in Pancreatic-venous inSULIN CONCENTRATIONS DURING PANCREATIC-ARTERIAL INFUSIONS OF KETONE BODIES ADMINISTERED AT A RATE OF 0.125 M MOLES PER MINUTE.

venous plasma insulin concentration that continued throughout the duration of the infusion (Table IV). Within 15 minutes mean insulin concentration increased $142 \%$ from the control value of 108 to $261 \mu \mathrm{U}$ per ml. By 80 minutes insulin concentration averaged $839 \mu \mathrm{U}$ per $\mathrm{ml}$, an eightfold increase from control (Figure 3 ).

\section{Discussion}

These data demonstrate that the pancreatic beta cells respond to hyperketonemia, induced by infusions of $\beta$-hydroxybutyrate and acetoacetate, with an increased rate of insulin secretion that

TABLE IV

Effect of pancreatic-arterial ketone infusion on pancreatic-venous insulin concentration

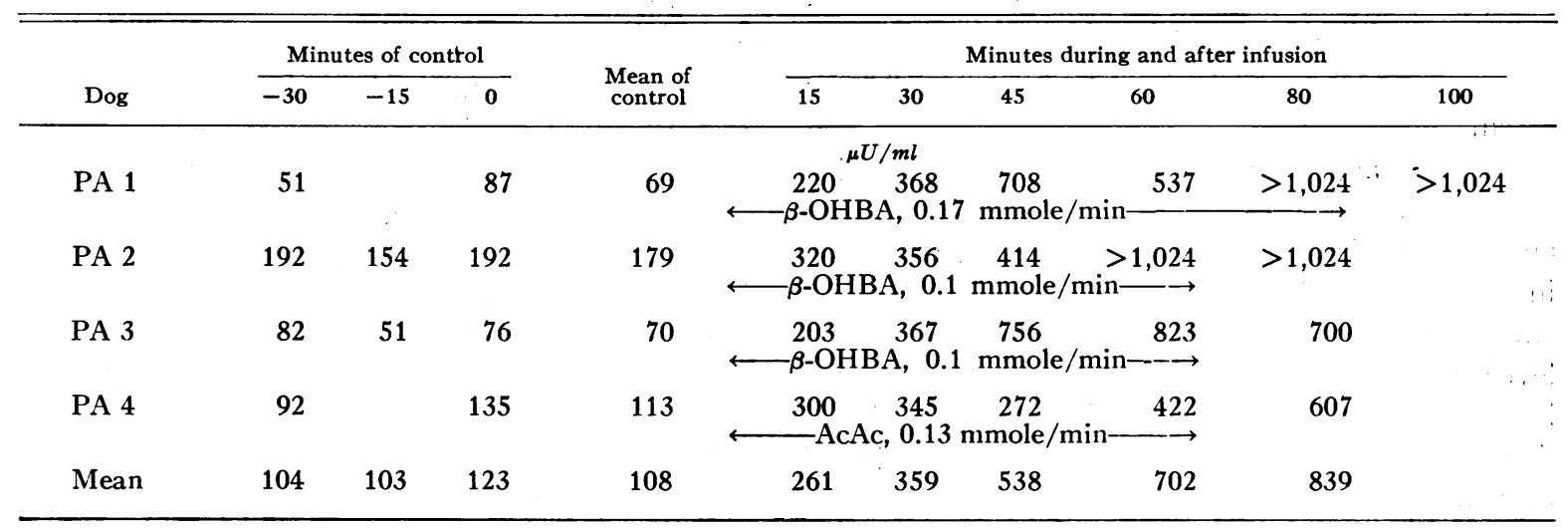


is immediate in onset and significant in amount. This release of endogenous insulin can account for the fall in arterial glucose concentration, the decline in plasma free fatty acid levels, and the reduction in hepatic glucose output previously reported from this laboratory $(18,19)$.

The failure of ketone infusions to lower blood glucose concentration in the two depancreatized dogs whose blood glucose levels in the control periods were maintained below $155 \mathrm{mg}$ per $100 \mathrm{ml}$ (Table II, dogs DP 1 and DP 2) with exogenous insulin suggests that ketones do not potentiate the action of insulin. That induced hyperketonemia caused a decline in blood glucose in the two alloxanized dogs with blood glucose levels greater than 200 and $300 \mathrm{mg}$ per $100 \mathrm{ml}$ (Table I) suggests that the release of insulin from the $\beta$-cells during hyperketonemia is via a mechanism different from the action of glucose.

The rapid increase in pancreatic-venous plasma insulin concentrations after pancreatic-arterial infusions of small amounts of ketones, coupled with the failure of similar loads of intravenously infused ketones to lower blood glucose concentration, indicates that the stimulating effect on the pancreatic beta cell is a direct one, not mediated by some intermediary product of ketone metabolism originating from extrapancreatic sources. That ketones may be metabolized rapidly by the pancreatic beta cells is suggested by Hellerström's (26) finding of pronounced activity of $\beta$-hydroxybutyric dehydrogenase in the pancreatic islets where its presence is limited to the beta cells.

Although these studies indicate that induced hyperketonemia stimulates the secretion of endogenous insulin, they offer no information about the precise levels of the stimulatory plasma ketones. In other studies from this laboratory (18, $19)$, the infusion of ketones at a rate producing plasma ketone levels of 3.5 mmoles per $\mathrm{L}$ within 20 minutes and 4.9 mmoles per $\mathrm{L}$ within $40 \mathrm{~min}-$ utes was associated with a fall in blood glucose and plasma NEFA concentrations and a reduction in hepatic glucose output. These changes occurred within 10 minutes before plasma ketone levels reached 3.5 mmoles per $\mathrm{L}$ and suggest that levels below this stimulate the secretion of endogenous insulin. Such stimulatory levels of plasma ketones occur during carbohydrate dep- rivation associated with either a high fat diet or complete starvation, where plasma ketone levels of 3.2 mmoles per $\mathrm{L}$ are not unusual and values as high as 6.5 mmoles per $L$ may be found $(2,4,27-30)$.

The data therefore suggest that the hyperketonemia characteristic of starvation or carbohydrate deprivation may have physiologically important effects on over-all fat, protein, and carbohydrate metabolism. The new steady state that emerges during prolonged fasting has been described previously and is conditioned by an altered hormonal background and a different substrate milieu which is available to the tissues as fuel for energy purposes (1-5, 31-38). The hyperketonemia of fasting may contribute to both the transition into and the maintenance of this new steady state in several ways.

First, the stimulatory effect of ketones on the pancreatic beta cells, by maintaining or even slightly increasing the secretion of endogenous insulin despite a falling arterial glucose concentration, may modulate the release of NEFA from the adipose tissue, regulate the rate of ketone production by the liver, and thereby prevent the development of progressive ketoacidosis. In this manner the molar concentration of NEFA and ketones may rise and then be maintained within relatively narrow limits at a new elevated level without the danger of fatal ketosis. Such changes in the concentration of plasma ketones and NEFA have been described during starvation $(4,5,27$, 29).

Second, the decrease both in arterial glucose concentration and in hepatic glucose output shown to result from the stimulatory effect of ketones on beta cells $(18,19)$ could act to conserve protein by reducing the availability of glucose for use by the peripheral tissues, since depleted glucose stores must otherwise be replenished by the catabolism of protein if the central nervous system, and therefore the organism, is to survive.

Third, hyperketonemia, per se, not only contributes to the different substrate milieu that characterizes the new steady state found during prolonged fasting but also influences the preferential use of substrate other than glucose by the peripheral tissues. During starvation there is a reciprocal increase in ketones and a fall in blood glucose concentration to a degree that the molar 
concentration of plasma ketones may equal or exceed that of glucose. Studies have been reported in which blood glucose levels have fallen from a control value of 5.1 to 3.8 mmoles per $\mathrm{L}$ after a 2-day fast (3) and to levels between 1.7 and 2.8 mmoles per $\mathrm{L}$ after 72 hours of fasting (4). Although plasma ketones are known to rise to levels between 3.5 and 5.0 mmoles per $\mathrm{L}$ during starvation of similar duration $(4,5,27$, $29)$, this relative and actual increase in plasma ketone concentration serves to increase the efficiency of ketones as a competitor of glucose for metabolism by the peripheral tissues and has been shown to inhibit peripheral glucose utilization. In previous, in vivo, studies from this laboratory $(18,19)$, ketone infusions were noted to produce a $30 \%$ reduction in the utilization of glucose by peripheral tissues. Inhibition of glucose oxidation by ketones also has been reported to occur in the eviscerated rabbit (39), the rat diaphragm (11), and the isolated perfused heart (40). Evidence indicating that ketones are the preferred fuel for oxidation by cardiac muscle has been reported by Williamson and Krebs (40).

This combination of a ketone-induced reduction in blood glucose concentration during the hyperketonemia of starvation, coupled with a ketonemediated inhibition of glucose utilization by peripheral tissues, may not only play a role along with the changes in NEFA (41), growth hormone $(34,38)$, and glucagon (5) in shifting the fuel used for energy purposes from carbohydrate to fat, but also may result in the slower dissipation of protein precursors of glucose and thereby conserve glucose for use by the brain, a tissue for which glucose is an obligatory substrate (42). Such changes in metabolism would be a distinct advantage for survival of the organism, since calories stored as fat could be used for over-all energy without the supervention of fatal ketoacidosis and at the same time permit glucose, produced by the liver from protein precursors and glycerol, to be portioned out gradually under circumstances where its utilization by the brain rather than the peripheral tissues is likely to occur.

Despite the fall in blood glucose with prolonged fasting, the concentration of plasma insulin and insulin-like activity measured by the immunoassay and fat pad technique may not be significantly altered from values found after an overnight fast $(4,5)$. The small but physiologically important variations in insulin secretion that occur secondary to changes in plasma ketone levels with fasting will probably be difficult to document from the measurement of changes in peripheral plasma concentrations by the presently available technique since insulin is secreted into the portal circulation and is trapped by the liver in significant amounts $(43,44)$. Small changes in insulin secretion, therefore, may not necessarily be reflected in peripheral plasma concentrations because of the sensitivity of the present technique and because of the variations in hepatic binding or insulin turnover rates, or both. It is reasonable to assume that some stimulus for altering insulin secretion rate in the presence of the depressed blood glucose concentration of fasting must occur; otherwise fatal ketoacidosis would result. The data from these studies suggest that hyperketonemia is this stimulus.

\section{Summary}

Seventeen experiments were performed on dogs to determine whether the hypoglycemic effect of ketones could be ascribed to an increased secretion of endogenous insulin. The failure of ketone infusions to lower blood glucose concentration in completely depancreatized dogs coupled with a fall in blood glucose in alloxanized dogs indicated that the pancreas is necessary for this hypoglycemic action. Intravenous infusions of $\beta$ hydroxybutyrate and acetoacetate resulted in a $200 \%$ increase in the concentration of insulin in the pancreatic-venous blood. The infusion of much smaller amounts of ketones directly into the pancreatic artery produced an eightfold increase in insulin secretion, indicating that ketones have a direct stimulatory effect on the beta cells.

We suggest that during fasting, with its characteristic hyperketonemia, the stimulatory effect of ketones on the beta cells may represent a feedback resulting in alterations in insulin secretion which then modulate NEFA release and ketone production and thereby prevent fatal ketoacidosis during prolonged starvation. Another topic discussed is the role of hyperketonemia in decreasing peripheral glucose utilization and conserving glucose for use by the central nervous system dur- 
ing the new steady state that characterizes starvation.

\section{References}

1. Lundbaek, K. Metabolic abnormalities in starvation diabetes. Yale J. Biol. Med. 1948, 20, 533.

2. Kartin, B. L., E. B. Man, A. W. Winkler, and J. P. Peters. Blood ketones and serum lipids in starvation and water deprivation. J. clin. Invest. 1944, 23, 824.

3. Craig, J. W., M. Miller, M. S. Mackensie, and H. Woodward, Jr. The influence of dietary carbohydrate deprivation on the metabolism of intravenously administered fructose and glucose in man. J. clin. Invest. 1958, 37, 118.

4. Wood, F. C., Jr., L. Domenge, P. R. Bally, A. E. Renold, and G. W. Thorn. Studies on the metabolic response to prolonged fasting. Med. Clin. N. Amer. 1960, 44, 1371.

5. Unger, R. H., A. M. Eisentraut, and L. L. Madison. The effects of total starvation upon the levels of circulating glucagon and insulin in man. J. clin. Invest. 1963, 42, 1031.

6. Campbell, J., and C. H. Best. Physiologic aspects of ketosis. Metabolism 1956, 5, 95.

7. McPherson, H. T., E. E. Werk, Jr., J. D. Myers, and F. L. Engel. Studies on ketone metabolism in man. II. Effect of glucose, insulin, cortisone and hypoglycemia on splanchnic ketone production. J. clin. Invest. 1958, 37, 1379.

8. Siperstein, M. D. Inter-relationships of glucose and lipid metabolism. Amer. J. Med. 1959, 26, 685.

9. Van Itallie, T. B., and S. S. Bergen, Jr. Ketogenesis and hyperketonemia. Amer. J. Med. 1961, 31, 909.

10. Beatty, C. H., R. D. Peterson, R. M. Bocek, and E. S. West. Acetoacetate and glucose uptake by diaphragm and skeletal muscle from control and diabetic rats. J. biol. Chem. 1959, 234, 11.

11. Neptune, E. M., Jr., H. C. Sudduth, F. J. Fash, and J. J. Reish, Jr. Metabolism of $\beta$-hydroxybutyrate and acetoacetate by excised rat diaphragm and homogenate. Amer. J. Physiol. 1961, 201, 235.

12. Beatty, C. H., A. Marcó, R. D. Peterson, R. M. Bocek, and E. S. West. Acetoacetic acid metabolism by skeletal muscle fibers from control and diabetic rats. J. biol. Chem. 1960, 235, 2774.

13. Nath, M. C., and H. D. Brahmachari. Experimental hyperglycemia by injection of intermediary fat metabolism products in rabbits. Nature (Lond.) 1944, 154, 487.

14. Nath, M. C., and H. D. Brahmachari. Relation of intermediary metabolites to the lowering of the potency of pancreatic insulin in the animal system. Nature (Lond.) 1948, 161, 18.

15. Tidwell, H. C., and H. E. Axelrod. Blood sugar after injection of acetoacetate. J. biol. Chem. 1948, 172, 179.
16. Neptune, E. M., Jr. Changes in blood glucose during metabolism of $\beta$-hydroxybutyrate. Amer. J. Physiol. 1956, 187, 451.

17. Neptune, E. M., Jr. Effect of ammonium intoxication on metabolism of $\beta$-hydroxybutyrate. Amer. J. Physiol. 1956, 187, 454.

18. Mebane, D., and L. L. Madison. The hypoglycemic action of ketones. I. Effects of ketones on hepatic glucose output and peripheral glucose utilization. J. Lab. clin. Med., in press.

19. Mebane, D., and L. L. Madison. The hypoglycemic effect of ketone bodies (abstract). J. clin. Invest. 1962, 41, 1383.

20. Madison, L. L., B. Combes, R. Adams, and W. Strickland. The physiological significance of the secretion of endogenous insulin into the portal circulation. III. Evidence for a direct immediate effect of insulin on the balance of glucose across the liver. J. clin. Invest. 1960, 39, 507.

21. Klebanoff, S. J., and A. L. Greenbaum. The effect of $\mathrm{pH}$ on the diabetogenic action of alloxan. J. Endocr. 1954, 11, 314.

22. Markowitz, J., J. Archibald, and H. G. Downie. Experimental Surgery, 4th ed. Baltimore, Williams and Wilkins, 1959, p. 351.

23. Somogyi, M. Determination of blood sugar. J. biol. Chem. 1945, 160, 69.

24. Colwell, A. R., Jr., J. A. Colwell, and A. R. Colwell. Intrapancreatic perfusion of the antidiabetic sulfonylureas. Metabolism 1956, 5, 749.

25. Yalow, R. S., and S. A. Berson. Immunoassay of endogenous plasma insulin in man. J. clin. Invest. 1960, 39, 1157.

26. Hellerström, C. Enzymes histochemistry of the pancreatic islets in the duck with special reference to the two types of A cells. Zeitschrift Zellforsch. 1963, 60, 688.

27. MacKay, E. M. The significance of ketosis. J. clin. Endocr. 1943, 3, 101.

28. Johnson, R. E., F. Sargent, Jr., and R. Passmore. Normal variations in total ketone bodies in serum and urine of healthy young men. Quart. J. exp. Physiol. 1958, 43, 339.

29. Wick, A. N., J. W. Sherrill, and E. M. MacKay. Degree of ketosis during fasting. Proc. Soc. exp. Biol. (N. Y.) 1940, 45, 437.

30. Drury, D. R., A. N. Wick, and E. M. MacKay. The action of exercise on ketosis. Amer. J. Physiol. 1941, 134, 761.

31. Engel, F. L. The influence of the endocrine glands on fatty acid and ketone body metabolism. Amer. J. clin. Nutr. 1957, 5, 417.

32. Hashim, S. A. Endocrine factors in lipid mobilization. Diabetes 1960, 9, 135.

33. Goodman, H. M., and E. Knobil. Some endocrine factors in regulation of fatty acid mobilization during fasting. Amer. J. Physiol. 1961, 201, 1.

34. Raben, M. S., and C. H. Hollenberg. Effect of growth hormone on plasma fatty acids. J. clin. Invest. 1959, 38, 484. 
35. Engel, H. R., D. M. Bergenstal, W. E. Nixon, and J. A. Patten. Effect of human growth hormone on UFA and plasma amino acid nitrogen in man. Proc. Soc. exp. Biol. (N. Y.) 1959, 100, 699.

36. Bennett, L. L., R. E. Kreiss, C. H. Li, and H. M. Evans. Production of ketosis by the growth and adrenocorticotropic hormones. Amer. J. Physiol. 1948, 152, 210.

37. Jansz, A., H. Doorenbos, and W. D. Reitsma. Effect of food intake on growth-hormone level. Lancet 1963, 1, 250.

38. Roth, J., S. M. Glick, R. S. Yalow, and S. A. Berson. Hypoglycemia: a potent stimulus to secretion of growth hormone. Science 1963, 140, 987.

39. Drury, D. R., and A. N. Wick. The effect of $\beta$-hydroxybutyric acid on glucose oxidation in insulinized animals. J. biol. Chem. 1952, 196, 129.
40. Williamson, J. R., and H. A. Krebs. Acetoacetate as fuel of respiration in the perfused rat heart. Biochem. J. 1961, 80, 540.

41. Randle, P. J., C. N. Hales, P. B. Garland, and E. A. Newsholme. The glucose fatty-acid cycle. Its role in insulin sensitivity and the metabolic disturbances of diabetes mellitus. Lancet 1963, 1, 785.

42. Fazekas, J. F. Pathologic physiology of cerebral dysfunction. Amer. J. Med. 1958, 25, 89.

43. Madison, L. L., B. Combes, R. H. Unger, and N. Kaplan. The relationship between the mechanism of action of the sulfonylureas and the secretion of insulin into the portal circulation. Ann. N. Y. Acad. Sci. 1959, 74, 548.

44. Madison, L. L., and N. Kaplan. The hepatic binding of $\mathrm{I}^{131}$-labeled insulin in human subjects during a single transhepatic circulation. Proc. Central Soc. clin. Res. 1958, 31, 59. 